\title{
Mineral mixtures from solid salt residues for lambs
}

\section{Daniel Bomfim Manera', Tadeu Vinhas Voltolini², Daniel Ribeiro Menezes ${ }^{1}$, Gherman Garcia Leal de Araújo²}

\author{
${ }^{1}$ Programa de Pós-graduação em Ciência Animal, Universidade Federal do Vale do São Francisco, Petrolina, PE, Brasil. \\ ${ }^{2}$ Embrapa Semiárido, Petrolina, PE, Brasil.
}

\begin{abstract}
The objective of this study was to evaluate water, mineral, feed and nutrient voluntary intakes, in addition to dry matter and nutrient digestibility and the nitrogen balance of lambs fed three mineral supplements. The first treatment consisted of solid salt residue (SSR) from an aquaculture tank; the second contained SSR from desalination waste; and the third treatment was control, which corresponded to the supplementation of a commercial mineral supplement. The study lasted 20 days, the first 15 of which were used for animals to adapt to the pens and diets, and the last five days were used for data collection. Twenty-four castrated male lambs with a body weight of $19.72 \pm 2.52 \mathrm{~kg}$ were utilized in the experiment. The mineral supplements evaluated did not affect the intake and digestibility of the dry matter and nutrients, the water and mineral-salt intake or nitrogen balance. Mineral supplements produced from the SSR from aquaculture tanks and from the desalination waste did not reduce feed, nutrient and water intakes or nutrient digestibility, which suggests that these raw materials can be used in the elaboration of mineral mixtures for lambs.
\end{abstract}

Key Words: desalination waste, mineral supplement, sheep

\section{Introduction}

One of the biggest obstacles of raising ruminants in the Brazilian semi-arid region is the feed scarcity, especially during the dry period of the year, which contributes to the inadequate productive rates and low profitability of the rural property (Santos et al., 2011). Among the feeding deficiencies, the importance of energy and protein is known, but mineral deficiencies are also of great relevance and should not be disregarded in the ruminant production systems.

Some mineral deficiencies reported in goats and sheep from the Brazilian semi-arid region are: phosphorus (P) (Silva et al., 2011), copper (Cu), zinc ( $\mathrm{Zn})$ (Marques et al., 2011), selenium (Se), cobalt (Co) (Riet-Correa, 2004; Mendonça Júnior et al., 2011), sodium (Na) (Riet-Correa, 2004) and calcium (Ca) (Mendonça Júnior et al., 2011; Riet-Correa, 2004), and they indicate that, for the animals reared in this region, several mineral elements may be required for supplementation.

On the other hand, mineral sources, currently regarded as environment pollutants capable of degrading the arable lands, may have the potential to be used in the formulation

Received June 18, 2013 and accepted July 3, 2014. Corresponding author: tadeu.voltolini@embrapa.br

http://dx.doi.org/10.1590/S1516-35982014000900005

Copyright (C) 2014 Sociedade Brasileira de Zootecnia. This is an Open Access article distributed under the terms of the Creative Commons Attribution Non-Commercial License, which permits unrestricted non-commercial use, distribution, and reproduction in any medium, provided the original work is properly cited. of mineral mixtures, as is the case of the solid salt residues (SSR), originated from aquaculture tanks filled with water with high salt contents, and the SSR from the desalination waste.

The solid salt residue (SSR) from desalination also presented a great amount of salts, especially $\mathrm{NaCl}$, as demonstrated by Porto et al. (2000), who evaporated $5,000 \mathrm{~L}$ of desalination and obtained $1.81 \mathrm{~kg}$ magnesium sulfate $\left(\mathrm{MgSO}_{4)}, 1.98 \mathrm{~kg}\right.$ calcium sulfate $\left(\mathrm{CaSO}_{4}\right), 28.93 \mathrm{~kg}$ sodium chloride $(\mathrm{NaCl}), 0.79 \mathrm{~kg}$ magnesium chloride $\left(\mathrm{MgCl}_{2}\right)$ and $0.27 \mathrm{~kg}$ calcium chloride $\left(\mathrm{CaCl}_{2}\right)$.

Thus, the objective was to evaluate three mineral supplements on mineral, feed and nutrient intakes and to determine the digestibility of dry matter (DM) and nutrients and the nitrogen balance $(\mathrm{N})$ for lambs.

\section{Material and Methods}

The experiment was conducted in August 2012, lasting 20 days, whose first 15 days were used for adaptation, and the five other days for data collection.

Twenty-four male castrated lambs of an undefined breed with an average body weight (BW) of $19.72 \pm 2.52 \mathrm{~kg}$ were distributed in a completely randomized design with eight replications. The utilized animals were previously weighed and identified with earrings. After, they received an anthelmintic drug and were housed in metabolic cages provided with troughs, drinkers and salt feeder. 
Three mineral supplements were evaluated: control (commercial mineral supplement) and two others composed of solid salt residues from an aquaculture tank (SSR aquaculture) and from the desalination waste (SSR waste) (Table 1).

For the manufacture of the supplements constituted by SSR from aquaculture tanks and from the waste, it was necessary to macerate these saline sources in a mortar until they reached a meal aspect. Subsequently, other mineral sources were included, e.g., dicalcium phosphate; calcitic limestone; zinc, copper, cobalt and manganese sulfates; sodium selenite; calcium iodate; sulfur powder; and sodium chloride, standardizing the inclusion of the SSR at $20 \%$ of DM of the mineral supplements.

The mineral supplements produced with the SSR (Table 2) were formulated to have a similar composition to the mineral supplements for sheep available in the market, whose values were: (in $\mathrm{g} \mathrm{kg}^{-1}$ ) Na - 125; $\mathrm{P}-71 ; \mathrm{Ca}-152$; $\mathrm{S}-15 ; \mathrm{Mg}-9$; and (in $\mathrm{mg} \mathrm{kg}^{-1}$ ) $\mathrm{Fe}-1,688 ; \mathrm{Mn}-1,649$; $\mathrm{Se}-21 ; \mathrm{Zn}-3,508 ; \mathrm{Co}-62 ; \mathrm{Cu}-463 ; \mathrm{Cr}-20$; Ni - 20; Mo - 300; and I - 82.

The experimental diet was composed of Tifton 85 hay (Table 3), in addition to a mineral supplement and water. The Tifton grass hay was chopped in a stationary chopper and offered twice daily, at $08.30 \mathrm{~h}$ and $15.00 \mathrm{~h}$. The amount of hay provided was calculated daily according to the intake on the previous day, considering orts of up to $10 \%$. Thirty grams of the mineral supplement and $4.0 \mathrm{~kg}$ of water were offered daily per animal.

During the period of data collection, voluntary intakes of mineral supplement, water and hay were recorded, and fecal and urinary outputs were quantified. The daily

Table 1 - Chemical composition of solid salt residues from aquaculture tank and from desalination waste

\begin{tabular}{lccc}
\hline \multirow{2}{*}{ Mineral } & \multirow{2}{c}{ Unit } & \multicolumn{2}{c}{ Solid salt residues } \\
\cline { 3 - 4 } & & Aquaculture tank & Desalination waste \\
\hline Nitrogen (N) & $\mathrm{g} \mathrm{kg}^{-1}$ & 21.10 & $\mathrm{NA}$ \\
Phosphorus (P) & $\mathrm{g} \mathrm{kg}^{-1}$ & 3.07 & 2.62 \\
Potassium (K) & $\mathrm{g} \mathrm{kg}^{-1}$ & 3.11 & 3.37 \\
Calcium (Ca) & $\mathrm{g} \mathrm{kg}^{-1}$ & 79.46 & 37.00 \\
Magnesium (Mg) & $\mathrm{g} \mathrm{kg}^{-1}$ & 2.26 & 70.62 \\
Sulfur (S) & $\mathrm{g} \mathrm{kg}^{-1}$ & 5.98 & 19.94 \\
Sodium (Na) & $\mathrm{g} \mathrm{kg}^{-1}$ & 5.11 & 580.88 \\
Chlorine (Cl) & $\mathrm{g} \mathrm{kg}^{-1}$ & 0.02 & 423.0 \\
Boron (B) & $\mathrm{mg} \mathrm{kg}^{-1}$ & $16,514.00$ & $\mathrm{NA}$ \\
Copper (Cu) & $\mathrm{mg} \mathrm{kg}^{-1}$ & 16.90 & 0.39 \\
Iron (Fe) & $\mathrm{mg} \mathrm{kg}^{-1}$ & $1,241.30$ & 6.96 \\
Manganese (Mn) & $\mathrm{mg} \mathrm{kg}^{-1}$ & 192.9 & 34.80 \\
Zinc (Zn) & $\mathrm{mg} \mathrm{kg}^{-1}$ & 225.50 & 173.9 \\
Nickel (Ni) & $\mathrm{mg} \mathrm{kg}^{-1}$ & 43.90 & 0.57 \\
Lead (Pb) & $\mathrm{mg} \mathrm{kg}^{-1}$ & 40.90 & 0.30 \\
Cadmium (Cd) & $\mathrm{mg} \mathrm{kg}^{-1}$ & 5.51 & 0.15 \\
Chromium (Cr) & $\mathrm{mg} \mathrm{kg}^{-1}$ & 24.40 & 0.23 \\
\hline
\end{tabular}

NA - not analyzed. supplies and orts in a 24-hour interval were also recorded. In this period, samples of feed, water, mineral supplement, feces and urine were collected and stored in a freezer, except for the mineral supplement, which was stored at room temperature.

To collect the feces, nappa-leather bags were attached to the animals by harnesses. Bags were emptied twice daily, at $08.00 \mathrm{~h}$ and $15.00 \mathrm{~h}$, and only $10 \%$ of the total feces produced were collected. For the collection of urine,

Table 2 - Proportions of ingredients and concentration of minerals in the mineral supplements used in this experiment $\left(\mathrm{g} \mathrm{kg}^{-1}\right)$

\begin{tabular}{|c|c|c|c|}
\hline \multirow{2}{*}{ Mineral source } & & \multicolumn{2}{|c|}{ Solid salt residues (SSR) } \\
\hline & & SSR waste & SSR aquaculture \\
\hline SSR waste & & 200.00 & - \\
\hline SSR aquaculture & & - & 200.00 \\
\hline Dicalcium phosphate & & 376.50 & 373.00 \\
\hline Zinc sulfate & & 7.36 & 7.36 \\
\hline Copper sulfate & & 1.69 & 1.68 \\
\hline Manganese sulfate & & 4.10 & 4.91 \\
\hline Sodium selenite & & 0.05 & 0.05 \\
\hline Calcium iodate & & 0.12 & 0.12 \\
\hline Sulfur sulfate & & 12.00 & 10.00 \\
\hline Cobalt sulfate & & 0.31 & 0.31 \\
\hline Sodium chloride & & 265.00 & 298.00 \\
\hline Calcitic limestone & & 133.00 & 105.00 \\
\hline \multicolumn{4}{|c|}{ Concentration of minerals in the supplements offered to lambs ${ }^{1}$} \\
\hline Mineral & Control & SSR waste & SSR aquaculture \\
\hline Phosphorus ( $\left.\mathrm{g} \mathrm{kg}^{-1}\right)$ & 81.10 & 73.79 & 71.00 \\
\hline Potassium $\left(\mathrm{g} \mathrm{kg}^{-1}\right)$ & 0.99 & 1.02 & 1.04 \\
\hline Calcium $\left(\mathrm{g} \mathrm{kg}^{-1}\right)$ & 197.63 & 145.78 & 193.11 \\
\hline Magnesium $\left(\mathrm{g} \mathrm{kg}^{-1}\right)$ & 15.18 & 7.17 & 6.62 \\
\hline Sulfur $\left(\mathrm{g} \mathrm{kg}^{-1}\right)$ & 9.29 & 9.80 & 10.67 \\
\hline Sodium ( $\left.\mathrm{g} \mathrm{kg}^{-1}\right)$ & 135.32 & 220.05 & 185.44 \\
\hline Copper $\left(\mathrm{g} \mathrm{kg}^{-1}\right)$ & 0.06 & 0.26 & 0.28 \\
\hline Iron $\left(\mathrm{mg} \mathrm{kg}^{-1}\right)$ & 4.56 & 5.51 & 5.52 \\
\hline Manganese $\left(\mathrm{mg} \mathrm{kg}^{-1}\right)$ & 1.31 & 1.01 & 1.14 \\
\hline Zinc $\left(\mathrm{mg} \mathrm{kg}^{-1}\right)$ & 1.92 & 0.72 & 0.84 \\
\hline
\end{tabular}

${ }^{1}$ Analyzed data.

Table 3 - Chemical composition of the Tifton 85 hay offered to animals

\begin{tabular}{lc}
\hline Nutrient & $\mathrm{g} \mathrm{kg}^{-1}$ of DM \\
\hline Dry matter & 872.0 \\
Organic matter & 927.5 \\
Crude protein & 113.2 \\
Ash & 72.5 \\
Ether extract & 18.9 \\
Total carbohydrates & 795.3 \\
Non-fibrous carbohydrates & 56.0 \\
Neutral detergent fiber & 739.4 \\
Neutral detergent fiber corrected for residual ash and protein & 711.5 \\
Acid detergent fiber & 372.5 \\
Neutral detergent insoluble nitrogen & 5.5 \\
Acid detergent insoluble nitrogen & 2.0 \\
Lignin & 75.8 \\
Neutral detergent insoluble ash & 2.0 \\
Neutral detergent insoluble protein & 27.3
\end{tabular}

DM - dry matter. 
properly sanitized plastic buckets containing $100 \mathrm{~mL}$ sulfur acid (10\%) were placed below the cages. The urine collected was filtered through a fine mesh with gauze, and then quantified with the aid of a graduated cylinder. After its volume was measured, the urine was stored in plastic containers for later analyses.

All the samples of feces, feeds and orts were pre-dried in a forced air-circulation oven at $55{ }^{\circ} \mathrm{C}$ for 72 hours, and then ground in a knife mill with $1 \mathrm{~mm}$ screen sieve. These samples were mixed to form a composite sample, and subsequently analyzed.

Samples of feeds, orts and feces were analyzed and dry matter $(\mathrm{DM})$, ash, organic matter $(\mathrm{OM})$, crude protein (CP), ether extract (EE), neutral detergent fiber (NDF), neutral detergent fiber corrected for residual ash and protein (NDFap), acid detergent fiber (ADF) and lignin contents were determined according to methodologies described by Silva \& Queiroz (2002). The acid (ADIN) and neutral (NDIN) detergent insoluble nitrogen compounds were determined according to Licitra et al. (1996).

The equation proposed by Sniffen et al. (1992) was used to estimate the total carbohydrate (TC) content: $\mathrm{TC}=100-(\% \mathrm{CP}+\% \mathrm{EE}+\% \mathrm{Ash})$. And to estimate the non-fibrous carbohydrates (NFC), the following equation was used: $\mathrm{NFC}(\%)=\% \mathrm{TC}-\% \mathrm{NDF}$, as recommended by Hall et al. (1999).

The concentrations of nitrogen, potassium, calcium, magnesium, sulfur, boron, copper, iron, manganese, zinc, sodium, chlorine and phosphorus present in the samples of feed and waste were determined according to methodologies described by Nogueira and Souza (2005).

Dry matter (DMI) and nutrient intakes in $\mathrm{g} /$ animal day $^{-1}$ were estimated according to the following equations: intake (I) $\left(\mathrm{g} /\right.$ animal day $\left.{ }^{-1}\right)=$ total DM, OM, CP, NDF, ash, EE, TC and NFC provided - amount of DM, OM, CP, NDF, ash, EE, TC and NFC in the orts.

The digestibilities (D) of DM, CP, OM, NDF, EE and TC were estimated by the total fecal collection method, calculated by equation proposed by Silva \& Leão (1979): $\mathrm{D}=[(\mathrm{DM}$ or nutrient intake $(\mathrm{g})-\mathrm{DM}$ or nutrients in the feces $(\mathrm{g}) /($ DM or nutrient intake $(\mathrm{g})] \times 100$.
Water intake (WI) was estimated by the equation: $\mathrm{WI}=(\mathrm{WS}-\mathrm{WL})-\mathrm{EVPW}$, in which WS = water supplied; $\mathrm{WL}=$ water left; and EVPW = evaporated water. The evaporated water was estimated by placing five plastic buckets along the shed, containing the same volume of water in the water drinker of animals.

The mineral supplement intake (MSI) was determined as: $\mathrm{MSI}=\mathrm{MSS}-\mathrm{MSL}$, in which MSS $=$ mineral supplement supplied; and MSL = mineral supplement left.

To determine intake and excretion, samples of diet and orts as well as feces and urine of each animal were analyzed for nitrogen concentration in each one of them. Afterwards, nitrogen balance (NB) was calculated by the following equation: $\mathrm{NB}=\mathrm{N}$ intake $-(\mathrm{N}$ feces $+\mathrm{N}$ urine $)$ and the percentage of nitrogen retained, as follows: net utilization $=(\mathrm{NB} \times 100) / \mathrm{N}$ intake.

Statistical analyses were carried out with the Statistical Analysis System (SAS, version 9.0), performing variance analyses, followed by the test of means (Tukey), considering probability values lower than $5 \%$ as significant $(\mathrm{P}<0.05)$.

\section{Results}

The mineral supplements did not affect DM, water or mineral supplement intakes by lambs (Table 4). The mean values were $677.40 \mathrm{~g} /$ animal day $^{-1}, 1,283.63 \mathrm{~g} /$ animal day $^{-1}$ and $4.62 \mathrm{~g}$ /animal day $^{-1}$ for DM, water and supplement intakes, respectively.

The different mineral supplements did not affect CP, NDF, OM, ash, EE, TC or NFC intakes (Table 5). Lambs ingested on average $75.18 \mathrm{~g} \mathrm{day}^{-1}$ of CP, $473.59 \mathrm{~g} \mathrm{day}^{-1}$ of $\mathrm{NDF}$ and $341.00 \mathrm{~g} \mathrm{day}^{-1}$ of TDN, equivalent to $11.09 \%$ of CP, $69.91 \%$ of NDF and $50.34 \%$ of TDN in the diet.

The apparent digestibility of DM and CP, NDF, OM, EE and TC were not affected by the mineral supplements (Table 6). Dry matter digestibility averaged $545.20 \mathrm{~g} \mathrm{~kg}^{-1}$; CP and NDF digestibilities were $647.30 \mathrm{~g} \mathrm{~kg}^{-1}$ and $570.40 \mathrm{~g} \mathrm{~kg}^{-1}$, respectively. Total nitrogen intake, excretion of nitrogen in the feces and in the urine, total nitrogen excretion and nitrogen balance were not affected by the different types of mineral supplements (Table 7).

Table 4 - Dry matter, water and mineral supplement intakes by lambs fed different mineral supplements

\begin{tabular}{lcccccc}
\hline \multirow{2}{*}{ Intake $\left(\mathrm{g} \mathrm{day}^{-1}\right)$} & \multicolumn{3}{c}{ Mineral supplement } & \multirow{2}{*}{ Mean } & SEM & P-value \\
\cline { 2 - 4 } & Control & SSR waste & SSR aquaculture & & 632.90 & 60.25 \\
Dry matter & 674.40 & 546.90 & 677.40 & & 0.24 \\
Water & 1250.20 & 1147.90 & 1283.63 & 1227.20 & 77.40 & 0.45 \\
Mineral supplement & 3.86 & 4.08 & 4.62 & 4.19 & 0.74 & 0.76 \\
\hline
\end{tabular}

SSR - solid salt residue; SEM - standard error of the mean; P-value - probability at $5 \%$. 
Table 5 - Nutrient intake by lambs fed different types of mineral supplement

\begin{tabular}{|c|c|c|c|c|c|c|}
\hline \multirow{2}{*}{ Intake $\left(\mathrm{g} \mathrm{day}^{-1}\right)$} & \multicolumn{3}{|c|}{ Mineral supplement } & \multirow{2}{*}{ Mean } & \multirow{2}{*}{ SEM } & \multirow{2}{*}{ P-value } \\
\hline & Control & SSR waste & SSR aquaculture & & & \\
\hline Crude protein & 79.99 & 65.18 & 80.36 & 75.18 & 6.82 & 0.22 \\
\hline Ether extract & 13.51 & 9.93 & 13.42 & 12.29 & 1.42 & 0.15 \\
\hline Ash & 45.00 & 36.00 & 46.00 & 42.33 & 3.93 & 0.18 \\
\hline Neutral detergent fiber & 505.30 & 408.86 & 506.60 & 473.59 & 45.29 & 0.24 \\
\hline Non-fibrous carbohydrates & 38.00 & 27.63 & 38.36 & 34.69 & 4.30 & 0.16 \\
\hline Organic matter & 636.87 & 517.00 & 638.73 & 597.55 & 56.84 & 0.25 \\
\hline Total carbohydrates & 543.36 & 387.71 & 544.95 & 492.00 & 58.40 & 0.12 \\
\hline Total digestible nutrients & 378.55 & 245.49 & 399.19 & 341.00 & 56.08 & 0.13 \\
\hline
\end{tabular}

SSR - solid salt residue; SEM - standard error of the mean; P-value - probability at $5 \%$.

Table 6 - Digestibility of dry matter and nutrients of Tifton 85 hay offered to lambs supplemented with different types of mineral

\begin{tabular}{|c|c|c|c|c|c|c|}
\hline \multirow{2}{*}{ Nutrient $\left(\mathrm{g} \mathrm{kg}^{-1}\right)$} & \multicolumn{3}{|c|}{ Mineral supplement } & \multirow{2}{*}{ Mean } & \multirow{2}{*}{ SEM } & \multirow{2}{*}{ P-value } \\
\hline & Control & SSR waste & SSR aquaculture & & & \\
\hline Dry matter & 547.70 & 511.10 & 576.80 & 545.20 & 50.00 & 0.65 \\
\hline Crude protein & 656.60 & 612.00 & 673.20 & 647.30 & 43.50 & 0.60 \\
\hline Neutral detergent fiber & 574.10 & 544.90 & 592.20 & 570.40 & 43.70 & 0.75 \\
\hline Organic matter & 573.70 & 542.50 & 599.60 & 571.90 & 46.30 & 0.69 \\
\hline Ether extract & 444.50 & 357.40 & 524.80 & 442.20 & 81.80 & 0.37 \\
\hline Total carbohydrates & 564.30 & 452.50 & 591.20 & 536.00 & 58.50 & 0.23 \\
\hline
\end{tabular}

SSR - solid salt residue; SEM - standard error of the mean; P-value - probability at $5 \%$

Table 7 - Nitrogen-related variables in lambs supplemented with different mineral supplements

\begin{tabular}{|c|c|c|c|c|c|c|}
\hline \multirow{2}{*}{ Variable $\left(\mathrm{g} \mathrm{day}^{-1}\right)$} & \multicolumn{3}{|c|}{ Mineral supplement } & \multirow{2}{*}{ Mean } & \multirow{2}{*}{ SEM } & \multirow{2}{*}{ P-value } \\
\hline & Control & SSR waste & SSR aquaculture & & & \\
\hline Total nitrogen intake & 11.66 & 9.49 & 11.72 & 10.09 & 0.99 & 0.22 \\
\hline Nitrogen excreted in the feces & 4.02 & 3.74 & 4.06 & 3.94 & 0.41 & 0.84 \\
\hline Nitrogen excreted in the urine & 0.33 & 0.41 & 0.33 & 0.35 & 0.07 & 0.71 \\
\hline Total nitrogen excretion & 4.31 & 4.11 & 4.36 & 4.26 & 0.43 & 0.91 \\
\hline Nitrogen balance & 7.34 & 5.37 & 7.35 & 6.69 & 0.77 & 0.14 \\
\hline
\end{tabular}

SSR - solid salt residue; SEM - standard error of the mean; P-value - probability at $5 \%$.

Table 8 - Intake of minerals from hay, mineral supplement and water, mineral requirements and mineral balance of lambs fed mineral supplements

\begin{tabular}{|c|c|c|c|c|c|c|c|c|c|c|c|}
\hline \multirow{2}{*}{ Variable } & $\mathrm{K}$ & $\mathrm{Ca}$ & $\mathrm{Mg}$ & $\mathrm{S}$ & $\mathrm{Na}$ & $\mathrm{Cl}$ & $\mathrm{P}$ & $\mathrm{Cu}$ & $\mathrm{Fe}$ & $\mathrm{Mn}$ & $\mathrm{Zn}$ \\
\hline & \multicolumn{7}{|c|}{$\mathrm{g} \mathrm{day}^{-1}$} & \multicolumn{4}{|c|}{$\mathrm{mg} \mathrm{day}^{-1}$} \\
\hline & \multicolumn{11}{|c|}{ Control } \\
\hline Hay mineral intake & 11.58 & 3.24 & 1.06 & 1.24 & 0.32 & 2.41 & 1.92 & 3.82 & 62.49 & 38.41 & 17.23 \\
\hline Supplement mineral intake & 0.00 & 0.76 & 0.06 & 0.04 & 0.52 & 0.00 & 0.31 & 0.22 & 17.59 & 5.07 & 7.40 \\
\hline Water mineral intake & 0.00 & 0.03 & 0.01 & 0.00 & 0.00 & 0.01 & 0.00 & 0.01 & 0.10 & 0.11 & 0.01 \\
\hline Total mineral intake & 11.58 & 4.03 & 1.13 & 1.28 & 0.84 & 2.42 & 2.23 & 4.05 & 80.18 & 43.59 & 24.64 \\
\hline Mineral requirements & 2.90 & 2.20 & 0.60 & 1.10 & 0.40 & 0.30 & 1.50 & 3.10 & 32.00 & 12.00 & 13.00 \\
\hline \multirow[t]{2}{*}{ Mineral balance } & 8.68 & 1.83 & 0.53 & 0.18 & 0.44 & 2.12 & 0.73 & 0.95 & 48.18 & 31.59 & 11.64 \\
\hline & \multicolumn{11}{|c|}{ Solid salt residue (SSR) from waste } \\
\hline Hay mineral intake & 9.39 & 2.63 & 0.86 & 1.01 & 0.26 & 1.95 & 1.55 & 3.10 & 50.68 & 31.15 & 13.97 \\
\hline Supplement mineral intake & 0.00 & 0.59 & 0.03 & 0.04 & 0.90 & 0.00 & 0.30 & 1.04 & 22.48 & 4.11 & 2.95 \\
\hline Water mineral intake & 0.00 & 0.03 & 0.00 & 0.00 & 0.00 & 0.00 & 0.00 & 0.01 & 0.10 & 0.10 & 0.01 \\
\hline Total mineral intake & 9.39 & 3.25 & 0.89 & 1.05 & 1.16 & 1.95 & 1.85 & 4.15 & 73.26 & 35.36 & 16.93 \\
\hline Mineral requirements & 2.90 & 2.20 & 0.60 & 1.10 & 0.40 & 0.30 & 1.50 & 3.10 & 32.00 & 12.00 & 13.00 \\
\hline \multirow[t]{2}{*}{ Mineral balance } & 6.49 & 1.05 & 0.29 & -0.05 & 0.76 & 1.65 & 0.35 & 1.05 & 41.26 & 23.36 & 3.93 \\
\hline & \multicolumn{11}{|c|}{ Solid salt residue from aquaculture } \\
\hline Hay mineral intake & 11.64 & 3.26 & 1.07 & 1.25 & 0.32 & 2.42 & 1.92 & 3.84 & 62.77 & 38.58 & 17.30 \\
\hline Supplement mineral intake & 0.00 & 0.89 & 0.03 & 0.05 & 0.86 & 0.00 & 0.33 & 1.29 & 25.52 & 5.27 & 3.87 \\
\hline Water mineral intake & 0.00 & 0.03 & 0.01 & 0.00 & 0.00 & 0.01 & 0.00 & 0.01 & 0.11 & 0.11 & 0.01 \\
\hline Total mineral intake & 11.64 & 4.18 & 1.11 & 1.30 & 1.18 & 2.43 & 2.25 & 5.14 & 88.40 & 43.96 & 21.18 \\
\hline Mineral requirements & 2.90 & 2.20 & 0.60 & 1.10 & 0.40 & 0.30 & 1.50 & 3.10 & 32.00 & 12.00 & 13.00 \\
\hline Mineral balance & 8.74 & 1.98 & 0.51 & 0.20 & 0.78 & 2.13 & 0.75 & 2.04 & 56.40 & 31.96 & 8.18 \\
\hline
\end{tabular}

Mineral intakes were estimated considering dry matter intakes of $0.68,0.55$ and 0.68 , respectively, for control, SSE aquaculture and SRR waste.

Mineral requirements from National Research Council (NRC, 2007) considering lambs with $20 \mathrm{~kg}$ of body weight. 
Most mineral requirements $(\mathrm{K}, \mathrm{Ca}, \mathrm{Mg}, \mathrm{S}, \mathrm{Na}, \mathrm{Cl}, \mathrm{P}$, $\mathrm{Cu}, \mathrm{Fe}, \mathrm{Mn}$ and $\mathrm{Zn}$ ) were supplied by mineral supplements provided in association with Tifton hay. Only for sulfur when lambs were supplemented with SSR waste was the mineral balance negative (Table 8).

\section{Discussion}

The average DMI in this study was very close to the $630 \mathrm{~g} /$ animal day ${ }^{-1}$ described by NRC (2007) for lambs in the same weight range ( $20 \mathrm{~kg}$ of body weight). Ferreira et al. (2009) also found similar DMI to that obtained herein: $650 \mathrm{~g} /$ animal day ${ }^{-1}$, working with lambs of about $20 \mathrm{~kg}$ of body weight fed roughage-based diets.

For mineral supplement intake, the animals fed the control supplement averaged $3.86 \mathrm{~g} / \mathrm{animal} \mathrm{day}{ }^{-1}$, whereas those fed the supplements containing SSR originated from the aquaculture tank and from the desalinization waste showed 4.62 and $4.08 \mathrm{~g} /$ animal day ${ }^{-1}$, respectively. These values are similar to the 2.08 and 3.7-4.2 $\mathrm{g} \mathrm{day}^{-1}$ of mineral supplement reported by Selaive-Villarroel et al. (1991) and Malafaia et al. (2004), respectively, for animals in the same weight range, indicating that the mixtures made with the SSR were well-accepted by lambs.

Regarding water intake, the mean value obtained in the present study was $1,227.2 \mathrm{~g} /$ animal day $^{-1}$, which is close to the $1,480 \mathrm{~g} /$ animal day ${ }^{-1}$ predicted by the equation described in the NRC (2007): TWI $\left(\mathrm{kg} \mathrm{day}^{-1}\right)=$ DMI $\left(\mathrm{kg} \mathrm{day}^{-1}\right) \times 3.86$ -0.99 , in which TWI $=$ total water intake and DMI $=$ dry matter intake. This difference can be related to factors such as breed, water content in the feed and physiological state of the animal.

Overall, the differences in nutrient intake are related to the DM intake and the participation of each nutrient in the diet. In this study, the diets were similar, because all animals were fed a diet based on Tifton 85 hay, and their DM intakes were similar and resulted in similar feed intake values.

The average CP intake $\left(80.0 \mathrm{~g} /\right.$ animal day $\left.^{-1}\right)$ was above the $70 \mathrm{~g} \mathrm{day}^{-1}$ described by the NRC (2007) for animals of $20 \mathrm{~kg} \mathrm{BW}$ at eight months of age due to the appropriate DM intake coupled with the $\mathrm{CP}$ content of the forage (11.32\% CP in DM). The CP intake in the present research was similar to that reported by Bernardino et al. (2009), who evaluated sheep diets based on elephant grass and concentrate ingredients with approximately $12 \%$ of $\mathrm{CP}$ in the DM and obtained CP intakes from 50 to $110 \mathrm{~g} /$ animal day $^{-1}$, which is consistent with the values found herein. In the same study, Bernardino et al. (2009) found average NDF intakes, in the diets with inclusion of 0 to $30 \%$ of coffee husks in the DM, of $550 \mathrm{~g} /$ animal day ${ }^{-1}$, which is close the $470 \mathrm{~g} /$ animal day ${ }^{-1}$ obtained in the present study.

Overall, nutrient intake (CP, NDF, OM, ash, NFC, TC) was appropriate for the animals, not showing any damage caused by supply and ingestion of the mineral supplements made with non-traditional ingredients on these parameters.

Moreover, the values found herein are in line with those reported in the literature, e.g. Bernardino et al. (2009), for CP; Gonzaga Neto et al. (2001), for EE; Bispo et al. (2007) for TC; and Medeiros et al. (2007), for NFC.

The average TDN intake of $348.6 \mathrm{~g}^{-1 a y^{-1}}$ was below the $420 \mathrm{~g} \mathrm{day}^{-1}$ described by the NRC (2007) for $20 \mathrm{~kg}$ animals aiming at weight gains of $100 \mathrm{~g} \mathrm{day}^{-1}$. This lower intake in relation to that predicted by the NRC (2007) was a result of the exclusive ingestion of Tifton 85 in the diet.

On average, the apparent dry matter digestibility of $54.52 \%$ was similar to the $58.17,61.53$ and $57.02 \%$ found by Wanderley et al. (2012) using leucaena, pigeon pea and elephant grass, respectively, in association with forage palm in diets for feedlot sheep with $30 \mathrm{~kg} \mathrm{BW}$. Still according to these authors, the OM digestibility varied from 51.25 to $70.71 \%$, which is consistent with the value obtained in the present study.

The digestibility of $\mathrm{CP}$ and NDF were respectively 64.73 and $57.04 \%$, and these results are similar to those found in the literature for sheep fed roughage-based diets. Gonzaga Neto et al. (2001) provided Panicum numidianum hay and Caesalpinia pyramidalis hay to feedlot sheep with $24.5 \mathrm{~kg}$ BW and obtained CP digestibility values between 63.4 and $65.7 \%$. Teles et al. (2010) found NDF digestibility coefficients varying from 57.5 to 61.1 in sheep with $18.2 \mathrm{~kg}$ BW fed elephant grass silage associated with different levels of dried cashew apple.

The similar total nitrogen intakes are a result of the similar intakes of DM $\left(0.68,0.55\right.$ and $\left.0.68 \mathrm{~kg} \mathrm{day}^{-1}\right)$ and protein $\left(0.08,0.07\right.$ and $0.08 \mathrm{~g} /$ animal day $\left.{ }^{-1}\right)$ for the control, SSR waste and SSR aquaculture treatments, respectively. The nitrogen output in the feces and urine was on average 3.94 and $0.35 \mathrm{~g} \mathrm{day}^{-1}$, respectively, and according to Oliveira et al. (2004) the higher $\mathrm{N}$ output in the feces may be related to the presence of acid detergent insoluble and/or indigestible protein, whereas the low $\mathrm{N}$ output in the urine was probably due to the lower urinary loss of ammonia, and consequent production of urea in the liver.

The intake and excretion of $\mathrm{N}$ in the feces and urine were very close to the values found by Martins et al. (2003), who evaluated intake and digestibility of DM, CP and gross energy of the silages of four genotypes of sorghum in sheep and found 8.0 to $11.93 \mathrm{~g} \mathrm{day}^{-1}$ for total $\mathrm{N}$ intake; 4.9 to $7.3 \mathrm{~g} \mathrm{day}^{-1}$ for nitrogen output in the feces; 0.3 to 
$0.4 \mathrm{~g} \mathrm{day}^{-1}$ for nitrogen output in the urine; and 2.7 to $4.8 \mathrm{~g} \mathrm{day}^{-1}$ for retained nitrogen.

It is important to emphasize that animals had a positive $\mathrm{N}$ balance, which, according to Souza (2010), demonstrates that they did not need to reallocate body protein reserves to meet their nutritional requirements.

Mineral balance considering the intake of minerals from supplement, hay and water was positive for the most of macro- and micronutrients (Table 8). Sulfur presented negative balance for SSR waste because lambs ingested $546.90 \mathrm{~g} \mathrm{day}^{-1}$ of DM and $36.00 \mathrm{~g} \mathrm{day}^{-1}$ of ash, although ingestion of DM and ash for control and SSR aquaculture were 674.40 to $677.40 \mathrm{~g} \mathrm{day}^{-1}$ and 45.00 and $46.00 \mathrm{~g} \mathrm{day}^{-1}$, respectively.

Considering the intake of macro- and micronutrients only from Tifton 85 hay, the mineral balance was negative for $\mathrm{Na}$ (control supplement), $\mathrm{S}$ and $\mathrm{Na}$ (SSR waste) and $\mathrm{Na}$ and $\mathrm{Cu}$ (SSR aquaculture), i.e., the hay was able to supply a large part of mineral requirements, suggesting that the additional intake of mineral supplement may be excessive. But even the additional intake of minerals supplement the levels obtained in the diets did not represent toxic values for animals.

Overall, the use of the SSR from the aquaculture tanks and from the desalination waste for the preparation of mineral supplements for sheep did not lower intake or digestibility of DM and nutrients, nor the $\mathrm{N}$ balance by the animal, which demonstrates the possibility of using these sources. However, further research is necessary, especially on the field, with studies of longer durations to better understand the animal responses to these mineral sources.

\section{Conclusions}

Mineral supplements produced from the solid salt residues from aquaculture tanks and from the desalination waste provide similar dry matter, nutrient and water intakes and dry matter and nutrient digestibility to those provided by the commercial mineral supplement.

\section{References}

Bernardino, F. S.; Garcia, R.; Tonucci, R. G.; Rocha, F. C.; Valadares Filho, S. C. and Pereira, O. G. 2009. Consumo e digestibilidade de nutrientes de silagens de capim elefante com casca de café, por ovinos. Revista Brasileira de Produção Animal 10:460-469.

Bispo, S. V.; Ferreira, M. A.; Véras, A. S. C.; Batista, A. M. V.; Pessoa, R. A. S. and Bleuel, M. P. 2007. Palma forrageira em substituição ao feno de capim-elefante. Efeito sobre consumo, digestibilidade e características de fermentação ruminal em ovinos. Revista Brasileira de Zootecnia 36:1902-1909.
Ferreira, A. C. H.; Neiva, J. N. M.; Rodriguez, N. M.; Santana, G. Z. M.; Borges, I. and Lôbo, R. N. B. 2009. Desempenho produtivo de ovinos alimentados com silagens de capim-lefante contendo sub-produtos do processamento de frutas. Revista Ciência Agronômica 40:315-322.

Gonzaga Neto, S.; Batista, A. M. V.; Carvalho, F. F. R.; Martínez, R. L. V.; Barbosa, J. E. A. S. and Silva, E. O. 2001. Composição bromatológica, consumo e digestibilidade in vivo de dietas com diferentes níveis de feno de catingueira (Caesalpinea bracteosa), fornecidas para ovinos Morada Nova. Revista Brasileira de Zootecnia 30:553-562.

Hall, M. B.; Hoover, W. H.; Jennings, J. P. and Webster, T. K. M. 1999. Method for partitioning neutral detergent soluble carbohydrates. Journal of the Science of Food Agriculture 79:2079-2086.

Licitra, G.; Hernandez, T. M. and Van Soest, P. J. 1996. Standardization of procedures for nitrogen fractionation of ruminant feeds. Animal Feed Science and Technology 57:347-358.

Malafaia, P.; Pimentel, V. A.; Freitas, K. P.; Coelho, C. D.; Brito, M. F. and Peixoto, P. V. 2004. Desempenho ponderal, aspectos econômicos, nutricionais e clínicos de caprinos submetidos a dois esquemas de suplementação mineral. Pesquisa Veterinária Brasileira 24:15-22.

Marques, A. V. S.; Soares, P. C.; Riet-Correa, F.; Mota, I. O.; Silva, T. L. A.; Borba Neto, A. V.; Soares, F. A. P. and Alencar, S. P. 2011. Teores séricos e hepáticos de cobre, ferro, molibdênio e zinco em ovinos e caprinos no estado de Pernambuco. Pesquisa Veterinária Brasileira 31:398-406.

Martins, R. G. R.; Gonçalves, L. C.; Rodrigues, J. A. S.; Rodriguez, N. M.; Borges, I. and Borges, A. L. C. C. 2003. Consumo e digestibilidade aparente da matéria seca, da proteína bruta e da energia de silagem de quatro genótipos de sorgo (Sorghum bicolor (L.) Moench) por ovinos. Arquivo Brasileiro de Medicina Veterinária e Zootecnia 55:341-345.

Medeiros, G. R.; Carvalho, F. F. R.; Ferreira, M. A.; Batista, A. M. V.; Alves, K. S.; Maior Júnior, R. J. S. and Almeida, S. C. 2007. Efeito dos níveis de concentrado sobre o desempenho de ovinos Morada Nova em confinamento. Revista Brasileira de Zootecnia 36:1162-1171.

Mendoça Júnior, A. F.; Braga, A. P.; Rodrigues, A. P. M. S.; Sales, L. E. M. and Mesquita, H. C. 2011. Minerais: importância de uso na dieta de ruminantes. Agropecuária Científica no Semi-Árido $7: 1-13$.

Nogueira, A. R. A. and Souza, G. B. 2005. Tecido vegetal. Manual de laboratórios: solo, água, nutrição vegetal, nutrição animal e alimentos. Embrapa Pecuária Sudeste, São Carlos.

National Research Council - NRC. 2007. Nutrient requeriments of small ruminants. 7th ed. National Academic Press, Washington, D.C.

Oliveira, R. V.; Lana, R. P.; Maldonado, F.; Pereira, O. G.; Freitas, A. W. P.; Queiroz, A. C.; Oliveira, M. V. M. and Moraes, E. P. 2004. Consumo, digestibilidade aparente de nutrientes e disponibilidade de minerais em ovinos, em função de diferentes níveis de cama de frango na dieta. Revista Brasileira de Zootecnia 33:1060-1070.

Porto, E. R.; Dutra, M. T. D.; Amorim, M. C. C. and Araújo, G. G. L. 2000. Uso da erva sal (Atriplex nummularia) como forrageira irrigada com água salina. EMBRAPA-CPATSA, Petrolina.

Riet-Correa, F. 2004. Suplementação mineral em pequenos ruminantes no semi-árido. Ciência Veterinária Tropical 7:112-130.

Santos, P. M.; Voltolini, T. V.; Cavalcante, A. C. R.; Pezzopane, J. R. M.; Moura, M. S. B.; Silva, T. G. F.; Bettiol, G. M. and Cruz, P. G. 2011. Mudanças climáticas globais e a pecuária: Cenários futuros para o Semiárido brasileiro. Revista Brasileira de Geografia Física 4:1176-1196.

Selaive-Villarroel, A. B.; Cattani, J. C.; Figueiró, P. R. P.; Oliveira, N. M. and Silva, J. G. C. 1991. Suplementação mineral em cordeiros desmamados. Pesquisa Agropecuária Brasileira 26:1275-1281.

Silva, D. J. and Queiroz, A. C. 2002. Análise de alimentos: métodos químicos e biológicos. Editora UFV, Viçosa, MG.

Silva, J. F. C. and Leão, M. I. 1979. Fundamentos de nutrição dos ruminantes. Livro Ceres, Piracicaba. 
Silva, T. R.; Simões, S. V. D.; Miranda Neto, E. G.; Pereira Filho, J. M.; Assis, A. C. O.; Aguiar, G. M. N.; Lima, F. A. and Riet-Correa, F. 2011. Efeitos da suplementação com fósforo em caprinos no semiárido do Nordeste brasileiro. Arquivo Brasileiro de Medicina Veterinária e Zootecnia 63:1268-1271.

Sniffen, C. J.; O'Connor, D. J.; Van Soest, P. J.; Fox, D. G. and Russell, J. B. 1992. A net carbohydrate and protein system for evaluating cattle diets: carbohydrate and protein availability. Journal of Animal Science 70:3562-3577.

Souza, R. A. 2010. Características fermentativas e nutricionais de silagens de cultivares de capim-búffel em diferentes idades de corte.
Dissertação (M.Sc.). Universidade Federal do Vale do São Francisco, Petrolina.

Teles, M. M.; Neiva, J. N. M.; Clementino, R. H.; Rêgo, A. C.; Cândido, M. J. D. and Restle, J. 2010. Consumo, digestibilidade de nutrientes e balanço de nitrogênio da silagem de capim-elefante com adição de pseudofruto de caju desidratado. Ciência Rural 40:427-433.

Wanderley, W. L.; Ferreira, M. A.; Batista, A. M. V.; Véras, A. S. C.; Bispo, S. V.; Silva, F. M. and Santos, V. L. F. 2012. Consumo, digestibilidade e parâmetros ruminais em ovinos recebendo silagens e fenos em associação à palma forrageira. Revista Brasileira de Produção Animal 13:444-456. 